\title{
Palavras da Editora
}

\begin{abstract}
A Revista História Oral, com este novo número, mais uma vez reafirma seu compromisso de se constituir num espaço de reflexão metodológica para as pesquisas nas áreas de ciências humanas. De acordo com essa orientação, História Oral deve funcionar como uma bússola, um instrumento de crítica e renovação para novos temas e pesquisas. Um segundo objetivo da Revista é funcionar como um canal de comunicação entre a diretoria executiva e os núcleos regionais de maneira a não só estimular a produção das diferentes regiões, mas também divulgar o estado atual das investigações na área.

Os artigos publicados apresentam contribuições interessantes para os estudos de gênero e militância política. O primeiro conjunto de textos - de Benito Bisso Schmidt, Linderval Augusto Monteiro e Jessie Jane Vieira de Sousa - destaca o papel das trajetórias de mulheres como Ilda Lameu, Gilda Marinho, Lila Ripoll e uma militante de esquerda que tiveram atuação destacada em importantes lutas políticas.

$\mathrm{O}$ artigo de Benito Schmidt investiga a produção de memórias a respeito de duas gaúchas que militaram no PCB nas décadas de 1940 e 1950: a jornalista Gilda Marinho (1906-1984) e a professora e literata Lila Ripoll (1905-1967). A primeira, apesar de haver participado de importantes organizações, campanhas e eventos promovidos pelos comunistas, normalmente tem sua militância negligenciada, muitas vezes lembrada como uma mulher ousada, extravagante, transgressora dos papéis de gênero vigentes e ligada à alta-sociedade porto-alegrense. Já Lila aparece freqüentemente, nas fontes do Partido, como a "comunista ideal", a militante corajosa e disciplinada, nas lembranças de seus companheiros.

O trabalho de Linderval Monteiro tem como objetivo explicitar a maneira como surgiu, desenvolveu-se e foi interrompida, através do assassinato, a liderança comunitária de Ildacilde do Prado Lameu. Conhecida como Ilda, atuou na Baixada Fluminense, região metropolitana do Rio de Janeiro em defesa das comunidades excluídas.
\end{abstract}


O trabalho de Jessie Jane Vieira de Souza problematiza as memórias de uma ex-presa política brasileira que, da prisão, vivenciou os diferentes golpes militares ocorridos no Cone Sul durante as décadas de 1960 e 1970. Através das memórias construídas por sua própria família, é possível captar as tragédias que marcaram as trajetórias dos exilados brasileiros que se encontravam, então, espalhados pela América Latina.

Igualmente dedicado ao tema da militância política, o artigo de Marluza Harres trabalha com os conflitos e silêncios que marcaram as memórias dos antigos petebistas do Rio grande do Sul. Ainda referenciado à discussão de gênero, o artigo de Marilda Aparecida de Menezes pretende analisar as memórias de mulheres camponesas no agreste pernambucano entre as décadas de 1920 e 1980. A partir dessas memórias, pretendeu-se compreender as representações e práticas do grupo estudado, bem como as transgressões e resistências às regras, modelos e valores sociais.

Encerram o volume o texto do professor Gisafran Mota Jucá, que analisa as experiências desenvolvidas pelos Grupos de Pesquisa dedicados à História Oral existentes em Fortaleza, nas Universidades Federal do Ceará (UFC) e Estadual do Ceará (UECE); e a resenha feita por Antonio Montenegro sobre o livro de Flávio Weinstein Teixeira, O Movimento e a Linha: Presença do Teatro de Estudante e do Gráfico Amador no Recife (1946-1964).

Marieta de Moraes Ferreira

Março de 2008 